\title{
RANCANG BANGUN APLIKASI PENDATAAN PENDUDUK BERBASIS WEB DI KELURAHAN BUGIS
}

\author{
Eri Sasmita Susanto ${ }^{1 *}$, Herfandi ${ }^{2}$, Mujahidin Patti Peilohy ${ }^{3}$ \\ ${ }^{1,2,3}$ Teknik Informatika, Universitas Teknologi Sumbawa \\ email: eri.sasmita.susanto@uts.ac.id*
}

\begin{abstract}
Abstrak: Pendataan penduduk dimaksudkan untuk meningkatkan efisiensi dalam hal pelayanan masyarkat. Kelurahan Bugis Kabupaten Sumbawa selama ini masih mempunyai sistem yang belum terkomputerisasi sehingga menyulitkan dan memperlambat dalam proses pengolahan data penduduk. Oleh karena itu perlu dilakukan penelitian untuk membangun aplikasi pengolahan data tersebut. Tujuan dari pengolahan data ini adalah untuk memberikan kemudahan kepada pegawai guna memberikan efisiensi dalam pelayanan masyarkat. Dalam implementasi ini digunakan bahasa pemograman PHP dan MySQL sebagai database. Metode pengumpulan data yang digunakan dalam penelitian ini yaitu metode wawancara, observasi, dokumentasi dan studi pustaka serta metode pengembangan perangkat lunak menggunakan metode waterfall. Adapun metode pengujian dalam penelitian ini menggunakan pengujian black-box yang dilakukan menguji perangkat lunak dari segi spesifikasi fungsional.
\end{abstract}

Kata Kunci : Black-Box, Kelurahan Bugis, Pengolahan Data, waterfall, Web,

\begin{abstract}
Population data collection is intended to increase efficiency in terms of community services. So far, Bugis Village, Sumbawa Regency, still has a system that has not been computerized, making it difficult and slow in the processing of population data. Therefore, it is necessary to conduct research to build data processing applications. The purpose of processing this data is to make it easy for employees to provide efficiency in community service. In this implementation, the programming language PHP and MYSQL are used as the database. Data collection methods used in this research are interview, observation, documentation and literature study methods as well as software development methods using the waterfall method. The test method in this study uses black-box testing which is done to test the software in terms of functional specifications.
\end{abstract}

Keywords : Black-Box, Bugis Village, Data Processing, waterfall, Web

\section{PENDAHULUAN}

Dalam era globalisasi saat ini, Perkembangan teknologi yang semakin cepat telah membawa kemajuan yang besar dalam berbagai bidang, baik di instansi pemerintah maupun swasta, terutama bagi negara maju seperti Indonesia. Peran dan dukungan teknologi sangat penting dalam proses kegiatan maupun aktivitas, Peran ini bertujuan mempermudah dan memperlancar jalanya aktivitas, baik itu kegiatan dalam sehari-hari maupun saat bekerja. Evektifitas dari sebuah pekerjaan sangat diperlukan mengingat padatnya aktivitas ataupun pekerjaan lain yang tidak bisa ditinggalkan. Dibutuhkan suatu penunjang yang dapat bekerja secara akurat dan cepat dalam mengelolah aktivitas ataupun kegiatan yang dapat mendukung tercapainya kinerja yang lebih evektif. Sistem terkomputerisasi adalah salah satu cara untuk mempermudah kinerja suatu instansi pemerintah sehingga dalam melakukan pengolahan data dapat dilakukan dengan akurat, cepat dan tepat.

Instansi pemerintah kelurahan Bugis yang beralamatkan di Jln. mawar No $02 \mathrm{Kec}$. Sumbawa Besar, Nusa Tenggara Barat merupakan Instansi yang bergerak dibidang pelayanan masyarkat yang saat ini telah memiliki jumlah penduduk kurang lebih 15000 (KK). Secara garis besar Kelurahan Bugis memiliki pekerjaan utama yaitu melakukan pelayanan seperti pendataan data warga, surat keterangan tidak mampu, data kartu keluarga, data warga, surat keterangan tidak mampu, data mutasi, galeri dan user.

Kelurahan Bugis masih menggunakan sistem pelayaanan yang belum terkomputerisasi dan masih dicatat pada buku besar. Dimana masyarakat diharuskan mengurus surat surat yang diinginkan pada instansi pemerintah dengan mengikuti prosedur yang berlaku, jadi jika warga ingin mengurus data untuk keperluannya, maka warga harus datang ke kantor kelurahan tersebut hanya untuk mengambil ataupun menyerahkan data Pada kantor kelurahan bugis. Sedangkan data yang ada di instansi pemerintah tersebut begitu banyak dan akan memakan waktu dan tenaga yang cukup lama.

Melihat masalah yang ada diatas, peneliti tertarik untuk meneliti dan membangun sebuah sistem informasi berbasis web dengan judul penelitian "Rancang Bangun Aplikasi Pendataan Penduduk Berbasis Web Di Kelurahan Bugis" yang diharapakan dapat membantu mengelolah data penduduk lebih baik dan maksimal. Oleh karena itu pihak kantor kelurahan dapat menemukan data secara cepat dan lebih memudah untuk memonitoring setiap harinya.

Berangkat dari permasalahan diatas, maka peneliti mencoba membuat solusi untuk mempermudah pelayanan masyarakat, yakni dengan merancang sebuah sistem pengolahan data yang dapat membantu kantor kelurahan bugis, untuk menjadi 
salah satu cara meningkatkan kualitas kerja serta mutu kantor kelurahan bugis tersebut agar lebif efisien.

\section{TINJAUAN PUSTAKA}

Dalam jurnal Anie Rose Irawati, Dwi Sakethi dan Alpiyan Zakki (2015) yang berjudul "Pengembangan Sistem Informasi Kependudukan Kecamatan Karya Penggawa Berbasis Web" yang bertujuan untuk memberikan kemudahan bagi staff kecamatan Karya Penggawa dalam pengolahan data Kependudukan, dapat menampilkan statistik data kependudukan dalam bentuk grafik yaitu berdasarkan Jenis Kelamin, Pendidikan, Pekerjaan, Agama dan Kelompok Umur juga dapat membantu staff kecamatan dalam mencetak hasil laporan statistik data kependudukan dengan langsung dicetak, format PDF serta format Excel.

\section{Dasar Teori}

\section{Rancang}

Menurut Pressman

(2010),

kata"rancang"merupakan kata sifat dari "perancangan" yakni merupakan serangkaian prosedur untuk menerjemahkan hasil analisis dari sebuah sistem ke dalam bahasa pemrograman untuk mendeskripsikan dengan detail bagaimana komponen-komponen sistem di implementasikan.

\section{Bangun}

Menurut Pressman (2010), kata "bangun" merupakan kata sifat dari "pembangunan" adalah kegiatan menciptakan sistem baru maupun mengganti atau memperbaiki sistem yang telah ada baik secara keseluruhan maupun sebagian dengan demikian pengertian rancang bangun merupakan kegiatan menerjemahkan hasil analisa ke dalam bentuk paket perangkat lunak kemudian menciptakan sistem tersebut ataupun memperbaiki sistem yang sudah ada.

\section{Kependudukan}

"Menurut BPS (2003:16), Penduduk merupakan semua orang yang berdomisili diwilayah geografis Republik Indonesia selama 6 bulan atau lebih dan meraka yang berdomisili kurang dari 6 bulan dengan tujuan untuk menetap.

Menurut Subri (2003:16), Pertumbuhan penduduk merupakan keseimbnagan yang dinamis antara kekuatan- kekuatan yang menambah dan mengurangi jumlah penduduk. Pertumbuhan penduduk diakibatkan oleh 4 komponen yaitu: kelahiran (fertilitas), kematian (mortalitas), migrasi masuk, dan migrasi keluar.

\section{Kelurahan Bugis}

Kelurahan bugis merupakan pembagian wilayah administartif di Indonesia dibawah kecamatan yang berdiri pada tahun 1985 yang beralamatkan di Jln. Mawar No 2 Kec.Sumbawa Besar, Nusa Tenggara barat. Kelurahan merupakan wilayah kerja lurah sebagai perangkat daerah kabupaten atau kota. Kelurahan dipimpin oleh seorang lurah yang berstatus sebagai pegawai Negeri Sipil. Kelurahan merupakan unit pemerintah terkecil setingkat dengan desa. Berbeda dengan desa, kelurahan memiliki hak untuk mengatur wilayahnya lebih terbatas. Dalam perkembanganya, sebuah desa dapat diubah statusnya menjadi kelurahan, atau sebaliknya.

\section{Unified Modelling Languange (UML)}

Menurut Rosa dan Shalahuddin (2013), Unified Modeling Language (UML) adalah salah satu standar bahasa yang banyak digunakan di dunia industri untuk mendefinisikan requirement, membuat analisis dan desain, serta menggambarkan arsitektur dalam pemrograman berorientasi objek. UML menyediakan serangkaian gambar dan diagram yang sangat baik. Beberapa diagram memfokuskan diri pada ketangguhan teori objec toriented dan sebagian lagi memfokuskan pada detail rancangan dan konstruksi. Semua dimaksudkan sebagai sarana komunikasi antar teamprogrammer maupun dengan pengguna .

Dalam penelitian skripsi ini penulis menggunakan 4 jenis diagram yaitu Harri gunawan, (2018) :

a. Use Case Diagram

Use case diagram merupakan pemodelan untuk kelakuan (behavior) sistem informasi yang akan dibuat. Use case digunakan untuk mengetahui apa saja yang ada di dalam sistem informasi dan siapa saja yang berhak menggunakan fungsifungsi tersebut.

b. Activity Diagram

Activity diagram menggambarkan work flow (aliran kerja) atau aktivitas dari sebuah sistem atau proses bisnis.

c. Sequence Diagram

Sequence diagram menggambarkan kelakuan objek pada use case dengan mendeskripsikan waktu hidup objek dan pesan yang dikirimkan dan diterima antar objek.

d. Class Diagram

Class diagram merupakan hubungan antar kelas dan penjelasan detail tiap-tiap kelas di dalam model desain dari suatu sistem, juga memperlihatkan aturan-aturan dan tanggung jawab entitas yang menentukan perilaku sistem.

\section{METODE PENELITIAN}

1. Alur Penelitian

Adapun Metode yang digunakan penelitian ini yaitu proses pengumpulan data dan metode pengembangan perangkat lunak. Adapun 
tahapan-tahapan yang digunakan dalam membangun sistem ini adalah sebagai berikut:

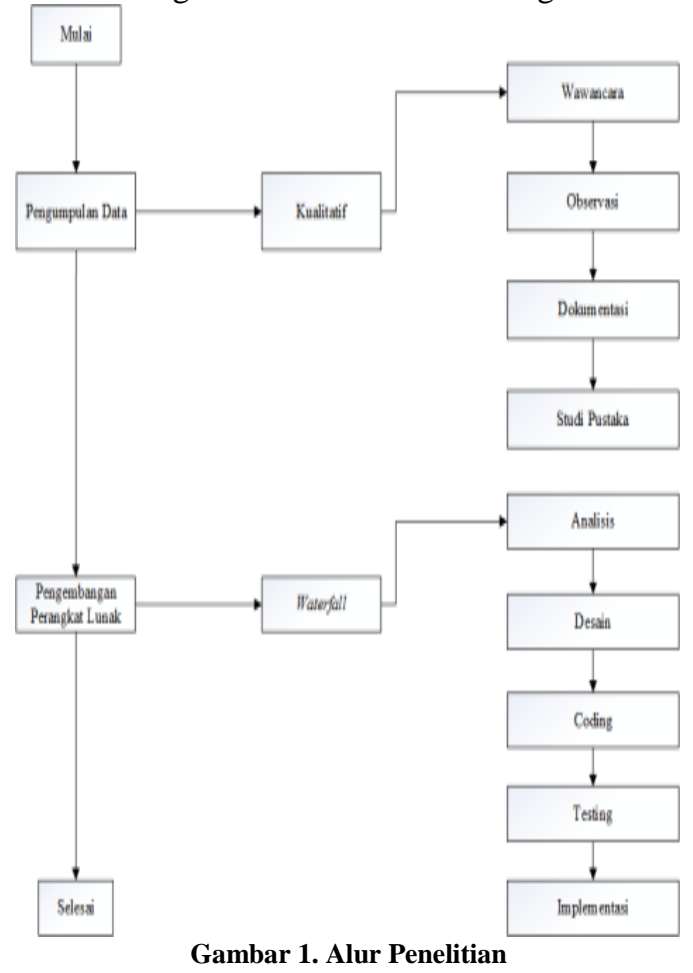

\section{Metode Pengumpulan Data}

Menurut (Moleong 2006) mendefinisikan metodologi kualitatif sebagai prosedur penelitian yang menghasilkan data deskriptif berupa kata kata tertulis atau lisan dari orangorang yang diamati secara langsung.

Berdasarkan pernyataan diatas peneliti sangat setuju dengan tanggapan dalam bertemu secara langsung. Karena keunggulan dari metode kualitatif sendiri adalah mampu menggali datadata dengan cara wawancara dan observasi serta dokumentasi secara langsung. Oleh karena itu peneliti berpendapat bahwa metode kualitatif sangat bagus untuk sistem yang ingin di bangun. Dalam pengembangan sistem, peneliti menggunakan metode kualitatif karena metode penggumpulan data yang digunakan dalam penelitian ini sangat terstruktur. Berikut langkah-langkah yang digunakan dalam metode peneliti:

a. Wawancara

Dengan metode wawancara ini dilakukan untuk mengumpulkan data secara langsung dengan cara melakukan tanya jawab dengan narasumber. Dalam penelitian skripsi ini penulis melakukan wawancara dengan kaur kepemerintahan mengenai masalah yang dialami dalam proses pengolahan data penduduk serta pelayanan kepada masyarakat kelurahan Bugis Kec. Sembawa Besar.

\section{b. Observasi}

Dengan metode observasi ini peneliti melakukan survey langsung untuk mengumpulkan data-data yang berkaitan dengan proses pelayanan kepada masyarakat dengan sistem pengolahan data penduduk dikantor kelurahan Bugis Kec. Sumbawa Besar.

c. Dokumentasi

Dengan metode dokumentasi ini peneliti mengumpulan data-data dengan teknik dokumentasi yang berkenaan dengan penelitian berupa gambar atau foto yang bersifat manual pada kantor kelurahan Bugis.

\section{d Studi Pustaka}

Studi pustaka merupakan salah satu teknik pengumpulan data yang bersumber dari bukubuku dan dokumen yang berhubungan dengan sistem yang dibangun pada penelitian. Studi kepustakaan yang digunakan untuk memperoleh data serta informasi dalam penelitian ini meliputi:

1.Jurnal dan tugas akhir yang berhubungan dengan judul penelitian.

2. Artikel yang digunakan adalah artikel yang diunduh dari internet yang berkaitan dengan masalah pada penelitian ini.

\section{Metode Pengembangan Perangkat Lunak}

Metode pengembangan perangkat lunak yang digunakan dalam penelitian skripsi ini adalah metode waterfal. Metode waterfall terdiri dari 5 fase antara lain:

a. Analisis Requetmen

Dalam pengembangan aplikasi berbasis web tahapan yang dilakuakan oleh seorang devoloper yaitu mencari tahu kebutuhan apa saja yang harus dilakukan agar mengatahui masalah yang ada pada instansi pemerintah kelurahan bugis.

\section{b. Desain}

Tahapan berikut adalah tahapan desain yang menjelaskan tentang masalah yang ada. Selanjutnya peneliti menganalisis kebutuhan sumber daya yang diperlukan dalam membuat sistem, seperti kebutuhan perangkat lunak, kebutuhan perangkat keras serta dapat membangun suatu sistem pada instansi pemerintah kelurahan bugis.

c. Coding 
Tahapan ini adalah tahapan perancangan dan permodelan sistem, setelah mengetahui kebutuhan yang diperlukan. Tujuannya untuk lebih memahami gambaran besar dari perancangan sistem informasi pengolahan data.

d. Testing

Tahapan ini merupakan tahap uji coba pengembangan aplikasi berbasis web yang telah dibuat. Desain menjadi kode, bentuk atau bahasa yang dapat dibaca oleh mesin. Setelah pengkodean selesai, dilakukan pengujian terhadap sistem yang sudah dibuat. Tujuanya untuk menemukan kesalahan yang mungkin terjadi untuk nantinya diperbaiki.

e Implementasi

Tahapan implementasi merupakan tahapan finising dalam pengembangan aplikasi berbasis $w e b$. Setelah itu dilakukan tahap pemeliharaan secara rutin.

\section{Alat Dan Bahan Penelitian}

Adapun alat dan bahan yang dibutuhkan dalam penelitian ini, yaitu analisis kebutuhan perangkat dan analisis kebutuhan data yang digunakan sebagai berikut :

\section{a. Analisis Kebutuhan Perangkat}

Adapun analisis kebutuhan perangkat dalam membangun sistem ini dibagi menjadi dua kebutuhan, yaitu kebutuhan perangkat keras dan kebutuhan perangkat lunak adalah sebagai berikut

Analisis kebutuhan perangkat keras (Hardware) Analisis kebutuhan perangkat keras yang dibutuhkan dalam membangun sistem adalah sebagai berikut :

Tabel 1 Analisis kebutuhan perangkat keras

\begin{tabular}{|c|c|c|}
\hline No & $\begin{array}{c}\text { Nama Perangkat } \\
\text { Keras }\end{array}$ & Keterangan \\
\hline 1. & Laptop & a) Processor \\
& & AMD A9-9420 \\
& & b) Memory \\
& & 4096MB RAM \\
& & c) Type AMD \\
& & Radeon Graphics \\
& & d) 500 GB HDD, \\
& & 128 GB SSD \\
\hline
\end{tabular}

Analisis kebutuhan perangkat lunak

Analisis kebutuhan perangkat lunak yang dibutuhkan dalam membangun sistem adalah sebagai berikut :
Tabel 2 Analisis kebutuhan perangkat lunak

\begin{tabular}{|c|c|c|}
\hline No & $\begin{array}{c}\text { Nama Perangkat } \\
\text { Lunak }\end{array}$ & Keterangan \\
\hline 1. & Sistem Operasi & Microsoft Windows 7 \\
\hline 2. & Php & Bahasa Pemograman \\
\hline 3. & MySql & 4.8 .5 \\
\hline 4. & Xampp Versi & V3.2.3 \\
\hline
\end{tabular}

5. Waktu Dan Tempat

Adapun waktu dan tempat penelitian yang digunakan dalam penelitian skripsi adalah sebagai berikut :

a. Waktu Penelitian

Penelitian ini dilaksanakan pada semester genap tahun ajaran 2020, yaitu antara bulan februari 2020 sampai dengan bulan april 2020.

\section{b. Tempat Penelitian}

Tempat penelitian ini berlokasi di kantor kelurahan bugis, tepatnya di Jln. Mawar 02 Kabupaten Sumbawa, Nusa Tenggara Barat.

\section{HASIL DAN PEMBAHASAN}

\section{Sistem Berjalan}

Berdasarkan hasil dari analisis yang telah dilakukan, penulis membuat alur sistem yang sedang berjalan dengan flowmap yang berfungsi untuk mencari permasalahan yang terjadi. Adapun flowmap sistem yang berjalan saat ini adalah sebagai berikut:



Gambar diatas adalah alur dari sistem yang berjalan saat ini, alur dimulai dari warga memberikan data diri ke petugas kelurahan, kemudian petugas menulis nama data-data yang sudah diberikan oleh warga dan dicatat kedalam buku besar, yang dimana pada proses pencatatan tersebut ada banyak adata yang di masukan seperti keterangan tidak mampu, data kartu keluarga, data mutasi, galeri, dan user. Dari sistem yang berjalan saat ini penulis menemukan beberapa 
permasalahan yang terjadi, permasalah pertama adalah petugas kelurahan harus mencatat data warga kedalam buku besar yang dimana buku tersebut mudah hilang dan rusak dan sewaktu - waktu dibutuhkan akan sulit untuk dicari. Sehingga sistem yang berjalan saat ini kurang efektif.

\section{Rancangan Sistem Usulan}

Adapun rancangan sistem usulan yang dilakukan dalam Rancang Bangun Aplikasi Pendataan Penduduk Berbasis Web di Kelurahan Bugis:

\section{a. Gambaran Umum Aplikasi}

Pada gambaran umum rancang bangun aplikasi ini menjelaskan tentang bagian-bagian yang terdapat dalam Rancang Bangun Aplikasi Pendataan Penduduk Berbasis Web di Kelurahan Bugis, yaitu:menu data warga, menu data kartu keluarga, menu data mutasi dan menu galeri. Adapun gambaran umum dari Rancang Bangun Aplikasi Pendataan Penduduk Berbasis Web di Kelurahan Bugis sebagai berikut :

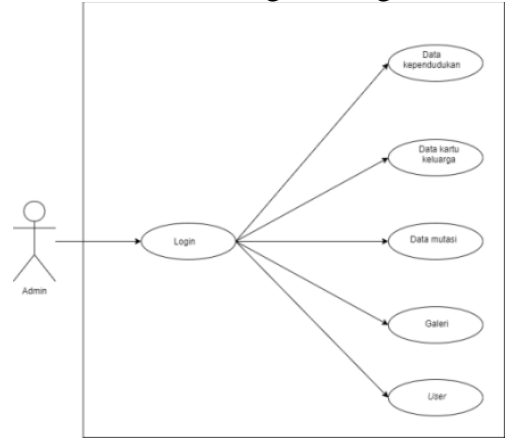

Gambar 3. Gambaran Umum Aplikasi

Pada usecase diagram user diatas aplikasi menampilkan login. Dihalaman login, admin akan memasukan username dan password. Setelah melakukan proses login admin selanjutnya masuk kehalaman dasboard yang akan menampilkan data kependudukan yang akan menampilakan kolom tambah data, lihat data, refresh dan cetak. Selanjutnya masuk ke halaman data kartu keluarga yang akan menampilkan kolom tambah data, lihat data, refresh dan cetak. Selanjutnya masuk ke halaman data mutasi yang akan menampilakan kolom lihat data, refresh, dan cetak. Selanjutnya masuk ke halaman galeri yang akan menampilakan kolom tambah data, lihat data. Selanjutnya masuk ke halaman user yang akan menampilkan kolom tambah data, lihat data, dan refresh.

\section{Implementasi Program}

Adapun implementasi program pada Rancang Bangun Aplikasi Pendataan Penduduk Berbasis Web di Kelurahan Bugis sebagai berikut :

a. Tampilan Login



Gambar diatas merupakan tampilan login dari Rancang Bangun Aplikasi Pendataan Penduduk Berbasis Web di kelurahan bugis. Dimana User atau pengguna harus login terlebih dahulu untuk dapat mengakses kedalam sistem.

b. Tampilan Data Warga

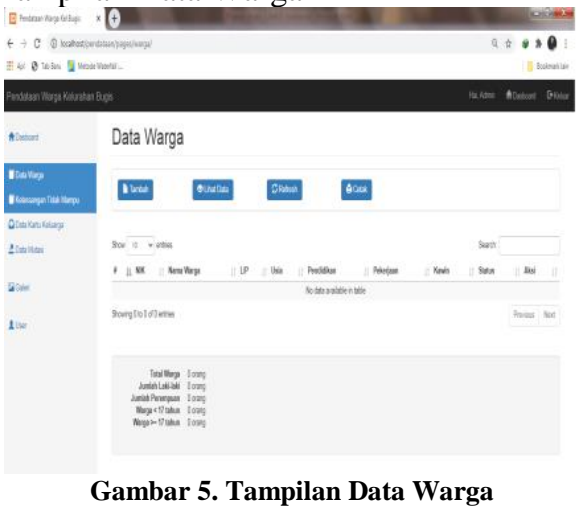

Gambar diatas merupakan tampilan data warga dari Rancang Bangun Aplikasi Pendataan Penduduk Berbasis Web di kelurahan bugis. Pada tampilan data warga, user atau pengguna dapat melihat data warga yang sudah ada pada halaman data warga serta dapat melakukan aksi pada data yang sudah ada dan memilih menu yang ada pada halaman data warga yaitu tambah data, refresh dan cetak. User atau pengguna memilih menu yang tersedia pada sistem yaitu menu dasboard, menu data kartu keluarga, menu data mutasi, menu galeri, menu user dan menu keluar.

\section{Tampilan Data Keluarga}




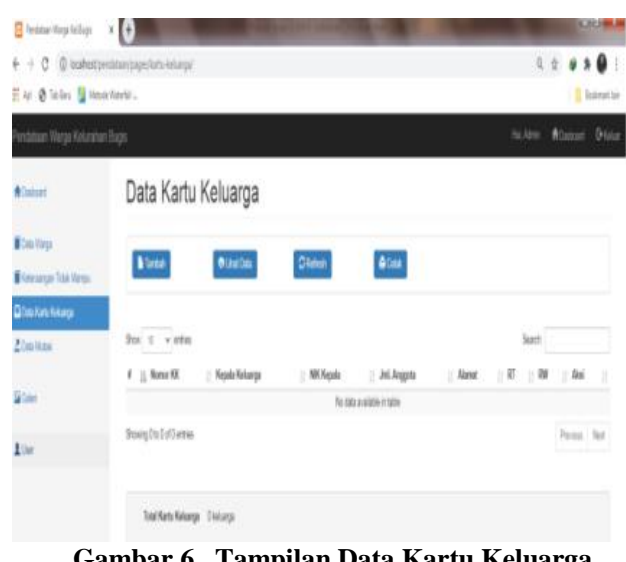

Gambar 6. Tampilan Data Kartu Keluarga

Gambar diats merupakan tampilan data kartu keluarga dari Rancang Bangun Aplikasi Pendataan Penduduk Berbasis Web di kelurahan bugis. Pada tampilan data kartu keluarga, user atau pengguna dapat melihat data kartu keluarga yang sudah ada pada halaman data kartu keluarga serta dapat melakukan aksi pada data yang sudah ada dan memilih menu yang ada pada halaman data kartu keluarga yaitu tambah data, refresh, dan cetak. User atau pengguna juga dapat memilih menu yang tersedia pada sistem yaitu menu dasboard, menu data kartu keluarga, menu data mutasi, menu galeri, menu user, dan menu keluar.

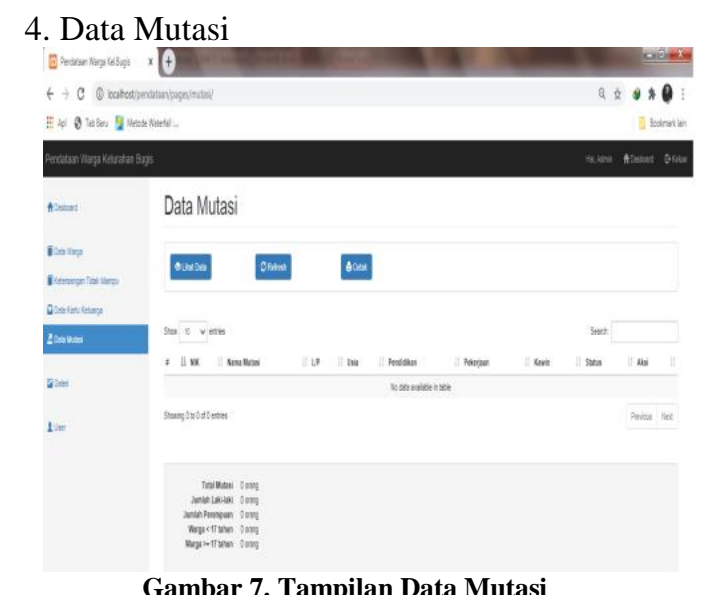

Gambar 7. Tampilan Data Mutasi

Gambar diatas merupakan tampilan data mutasi dari Rancang Bangun Aplikasi Pendataan Penduduk Berbasis Web di kelurahan bugis. Pada tampilan data mutasi, user atau pengguna dapat dapat melihat data mutasi yang sudah ada pada halaman data mutasi serta dapat melakukan aksi pada data yang sudah ada dan memilih menu yang ada pada halaman data mutasi yaitu tambah data, refresh, dan cetak. User atau pengguna juga dapat memilih menu yang tersedia pada sistem yaitu menu dasboard, menu data warga, menu data kartu keluarga, menu galeri, menu user, dan menu keluar.

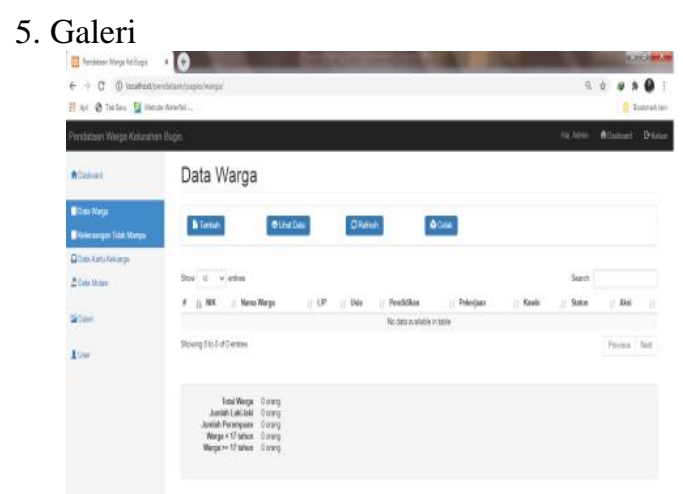

Gambar 7. Tampilan Galeri

Gambar diatas merupakan tampilan data galeri dari Rancang Bangun Aplikasi Pendataan Penduduk Berbasis Web di kelurahan bugis. User atau pengguna dapat melihat data galeri yang sudah ada pada halaman galeri serta dapat melakukan aksi pada data yang sudah ada dan memilih menu yang ada pada halaman galeri yaitu tambah galeri dan refresh. User atau pengguna juga dapat memilih menu yang tersedia pada sistem yaitu menu dasboard, menu data warga, menu data kartu keluarga, menu data mutasi, menu user, dan keluar.

\section{KESIMPULAN DAN SARAN}

\section{Kesimpulan}

Berdasarkan urain diatas maka dapat ditarik kesimpulan bahwa aplikasi ini dibuat untuk Pendataan penduduk dalam pengolahan data warga telah selesai dibangun menggunakan bahasa pemograman PHP dan database MySql dengan tingkat kesesuain pengujian black box mencapai 100, penulis berharap dengan adanya aplikasi ini dapat mempurmudah dalam proses melakukan pengolahan data penduduk agar lebih efektif dan efisien.

\section{Saran}

Dari Rancang Bangun Aplikasi Pendataan Penduduk Berbasis Web Di Kelurahan Bugis diatas, penulis memberikan saran agar selanjutnya dapat dilakukan pengembangan pada sistem diantara lain meliputi:

1. Menambah fitur sms geteway, agar masyarakat yang terdaftar di sistem informasi mendapatkan informasi kelurahan secara otomatis ke nomor telepon masyarakat.

2. Perlu adanya desain tampilan yang menarik lagi, supaya aplikasi yang kita gunakan tidak membosankan.

3. Kedepannya diharapkan bisa terintegrasi dengan data yang ada di Dinas Kependudukan dan Pencatatan 
Sipil kabupaten Sumbawa, agar data yang dikelola sesuai dengan data yang ada di Pemerintah Pusat.

\section{DAFTAR PUSTAKA}

A.S, Rosa, M. Shalahuddin. 2013. Rekayasa Perangkat Lunak. Informatika. Bandung.

Hariyanto, Agus, 2015, Membuat Aplikasi Computer Based Test dengan PHP MySQL dan Bootstrap, Penerbit Andi, Yogyakarta.

Haswan, Febri. 2018. Perancangan Sistem Informasi Pendataan Penduduk Kelurahan Sungai Jering Berbasis Web Dengan Object Oriented Programming. Jurnal Teknologi Dan Open Source, VOL. 1 No. 2, Desember 2018. Diakses 26 Desember 2020.

Irawati, Anie Rose. Dwi Sakethi dan Alpiyan Zakki. 2015. Pengembangan Sistem Informasi Kependudukan Kecamatan Karya Penggawa Berbasis Web. Jurnal Komputasi, Vol. 3, No. 2, 2015. Diakses 26 Desember 2020.

Kadir, 2003. Penerapan waterfall dalam analisis dan perancangan sistem informasi manajamen surat menyurat pada bank BJB kantor cabang BSD tanggerang, jurnal. Uin, Vol.12, No 12014.

Moleong, j, Lexy. 2016. Metodologi Penelitian Kualitatif.Bandung: PT. Remaja Rosdakarya. 